\title{
Research on the Grading Model of Financial Risk Alarm Condition Based on Extension Discrimination
}

\author{
Chen Yuan \\ Management Department \\ Independent College of Project\&Technology in \\ Hubei University of Technology \\ Wuhan, China \\ dilly12@sohu.com
}

\author{
Yang Yi \\ College of Economics\&Management \\ HuaZhong Agricultural University \\ Wuhan, China \\ yangyi09@mail.hzau.edu.cn
}

\begin{abstract}
According to the basic principle and method of extension discrimination, this paper constructs an extension discrimination grading model of enterprise's financial risk alarm condition based on the financial risk monitoring indicators. Then it measures and grades the financial risk alarm condition of some listed companies using financial indicators. The model and method will supply a management tool of financial risk for the investors' decision, securities market management department's supervision and internal managers' management.
\end{abstract}

Keywords-extension evaluation; financial risk; matter-element model; grading model

\section{INTRODUCTION}

Because science and technology changes quickly and competition in market becomes intensive increasingly, so market environment also changes quickly. So enterprise faces some uncertainty event in market and financing risk accompanies nearly each enterprise. Enterprises' management idea, technology and system are all facing severe challenge. So called financial risk is the risk induced by debt crisis. The crisis displays as the badness of financial status which influenced by uncertainty factors. It is especially important to judge financial risk condition accurately and determine the grade of financial risk alarm condition in the research of evaluation method of financial $\operatorname{risk}[1]$.

\section{MATTER-ELEMENT MODEL CONSTRUCTION OF FINANCIAL RISK ALARM CONDITION}

Anything can be described with three factors which include "things, characteristic, value", so as to analyze and calculate the things qualitatively and quantitatively. The ordered triad composed of the three factors is named matterelement which is the fundamental element to describe things. If " $\mathrm{R}$ " represents matter-element, " $\mathrm{M}$ " represents things, " $\mathrm{C}$ " represents M's characteristic, so $V(x)$ represents the measure value corresponding to " $\mathrm{C}$ ". $V(x)$ is membership corresponding to C's measure value, so set $\mathrm{R}=$ (things, characteristic, value $)=(\mathrm{M}, \mathrm{c}, \mathrm{v})$ [2].

If the quantity of financial risk alarm condition grading indicators is $\mathrm{m}$, set the indicators are $c_{1}, c_{2}, \cdots, c_{m}$. Based on the indicators, set the financial risk alarm condition has $\mathrm{n}$ level grades, which is described as a comprehensive matterelement model as below. The model represents the "classical field" in extension discrimination.

$$
R_{j}=\left[\begin{array}{ccc}
N_{j} & c_{1} & V_{j 1} \\
& c_{2} & V_{j 2} \\
\cdots & \cdots \\
& c_{m} & V_{j m}
\end{array}\right]=\left[\begin{array}{ccc}
N_{j} & c_{1} & <a_{j 1}, b_{j 1}> \\
& c_{2} & <a_{j 2}, b_{j 2}> \\
\cdots & \ldots \\
& c_{m} & <a_{j m}, b_{j m}>
\end{array}\right] j=1,2, \cdots, n
$$

In formula (1), ${ }^{R}$ represents the matter-element model of the $\mathrm{j}_{\mathrm{th}}$ financial risk alarm condition grade, ${ }^{N_{j}}$ represents the $\mathrm{j}_{\mathrm{th}}$ grade of financial risk alarm condition, $V_{j k}=\left\langle a_{j k}, b_{j k}\right\rangle$ represents the value range of the $\mathrm{k}_{\mathrm{th}}$ indicator in the $\mathrm{j}_{\mathrm{th}}$ grade. Matter-element model formed with the measure indicator's allowable value range is named sectional field. The formula of sectional field is shown as follow.

$$
R_{p}=\left[\begin{array}{ccc}
N_{p} & c_{1} & V_{p 1} \\
& c_{2} & V_{p 2} \\
\ldots & \ldots \\
& c_{m} & V_{p m}
\end{array}\right]=\left[\begin{array}{ccc}
N_{p} & c_{1} & <a_{p 1}, b_{p}> \\
& c_{2} & <a_{p 2}, b_{p}> \\
\ldots & \ldots \\
& c_{m} & <a_{p m}, b_{p}>
\end{array}\right]
$$

In formula (2), $R_{p}$ represents sectional field of matterelement model of financial risk alarm condition, $N_{p}$ represents all the grades of financial risk alarm condition. $V_{p k}=<a_{p k}, b_{p k}>$ represents allowable value range of the indicator $c_{k}$ in $N_{p}$, in the formula $, V_{j k} \subset V_{p k}, \mathrm{j}=1,2, \cdots, \mathrm{n}$, $\mathrm{k}=1,2, \cdots, \mathrm{m}$. Enterprise's financial risk alarm condition is represented by the matter-element model as follow.

$$
R=\left[\begin{array}{ccc}
N & c_{1} & V_{1} \\
& c_{2} & V_{2} \\
& \cdots & \cdots \\
& c_{m} & V_{m}
\end{array}\right]
$$


In formula (3), $\mathrm{R}$ represents matter-element model of enterprise's financial risk alarm condition, $\mathrm{N}$ represents enterprise's financial risk alarm condition, $V_{k}$ represents the value of the $\mathrm{k}_{\mathrm{th}}$ indicator.

\section{EXTENSION DISCRIMINATION MODEL CONSTRUCTION OF ALARM CONDITION GRADING}

After construction of matter-element model of enterprise's financial risk alarm condition, then we should grade each single indicator's financial risk alarm condition and the comprehensive financial risk alarm condition. So we should calculate the membership value between financial risk alarm condition matter-element model and its classical field. In actual evaluation, there are different calculating methods of membership value with concrete indicators[3]. The common method is elementary correlative model in extension discrimination as follow.

$$
\begin{aligned}
& \rho\left(V_{k}, V_{j k}\right)=\left|V_{k}-\frac{a_{j k}+b_{j k}}{2}\right|-\frac{b_{j k}-a_{j k}}{2}, j=1,2, \cdots, n ; k=1,2, \cdots, m \\
& \rho\left(V_{k}, V_{p k}\right)=\left|V_{k}-\frac{a_{p k}+b_{p k}}{2}\right|-\frac{b_{p k}-a_{p k}}{2}, j=1,2, \cdots, n ; k=1,2, \cdots, m
\end{aligned}
$$

Formula (4) and (5) represent $V_{k}$ 's memberships value of the intervals which include $V_{j k}$ and $V_{p k}$. When $\rho\left(V_{k}, V_{j k}\right) \geq 0$ or $\rho\left(V_{k}, V_{p k}\right) \geq 0$, it represents $V_{k}$ is not in $V_{j k}$ or $V_{p k}$; when $\rho\left(V_{k}, V_{j k}\right) \leq 0$ or $\rho\left(V_{k}, V_{p k}\right) \leq 0$, it represents $V_{k}$ is in $V_{j k}$ or $V_{p k}$. In addition, different negative value represents that $V_{k}$ 's location is different in $V_{j k}$ or $V_{p k}$.

$$
D\left(V_{k}, V_{j k}, V_{p k}\right)=\left\{\begin{array}{l}
\rho\left(V_{k}, V_{p k}\right)-\rho\left(V_{k}, V_{j k}\right), V_{k} \notin V_{j k} \\
-1, V_{k} \in V_{j k}
\end{array}\right.
$$

Formula (6) represents $V_{k}$ 's location value of $V_{j k}$ and $V_{p k}$.

$$
K_{j}\left(V_{k}\right)=\frac{\rho\left(V_{k}, V_{j k}\right)}{D\left(V_{k}, V_{j k}, V_{p k}\right)}, \mathrm{j}=1,2, \cdots, \mathrm{n}, \mathrm{k}=1,2, \cdots, \mathrm{m}
$$

Formula (7) represents the $\mathrm{k}_{\mathrm{th}}$ measurement indicator $c_{k}$ 's of the $j_{\text {th }}$ enterprise financial risk alarm condition level. When $K_{j}\left(V_{k}\right) \geq 0$, it represents that $V_{k}$ belongs to $V_{j k} . V_{j k}$ represents that $V_{k}$ has how many attributions of $V_{j k}$. When $K_{j}\left(V_{k}\right) \leq 0$, it represents that $V_{k}$ does not belong to $V_{j k}$. $K_{j}\left(V_{k}\right)$ represents the distance between $V_{k}$ and $V_{j k}$.

So we can calculate each financial risk measuring single indicator's correlative degree matrix with each alarm grade. The matrix is described as $K=\left[K_{j}\left(V_{k}\right)_{m \times n}\right]$, so:

$$
\max _{1 \leq j \leq n} K_{j}\left(V_{k}\right)=K_{i}\left(V_{k}\right)=K^{*}\left(V_{k}\right), k=1,2, \cdots, m
$$

$K_{i}\left(V_{k}\right)$ represents the $\mathrm{k}_{\mathrm{th}}$ indicator's financial risk alarm condition placing in the $\mathrm{i}_{\text {th }}$ grade. $K_{i}\left(V_{k}\right)$ decides the grades of each single indicator's financial risk alarm condition. Enterprise's financial risk comprehensive alarm condition's correlative degree of the $j_{\text {th }}$ grade is as follow[4].

$$
K_{j}(R)=\sum_{i=1}^{n} \lambda_{i} K_{j}\left(V_{i}\right), \quad j=1,2, \cdots, n
$$

Through the formula $K_{j}\left(V_{k}\right)=\max _{1 \leq j \leq n} K_{j}(R)$, enterprise's financial risk comprehensive alarm condition placing in the $\mathrm{j}_{\text {th }}$ grade.

In addition, " $i$ " represents the grade of each single indicator's financial risk alarm condition. The single indicator with the maximal " $\mathrm{i}$ " is the critical control point. Furthermore, maybe there is not only one critical control point.

\section{APPLICATION EXAMPLE OF FINANCIAL RISK ALARM CONDITION GRADING MODEL}

Based on the above theoretical model and method, according to 《Industry Classification Guide of Listed Company in China $》$, the paper chooses 17 listed companies in social service industry and grades their financial risk alarm condition to explain the application of the discrimination model.

There are 7 selected measuring indicators including $c_{1}-c_{7}$ in the application example. The indicators are described as $c_{1}=$ net asset earning rate, $c_{2}=$ operating income growth rate, $c_{3}=$ current ratio, $c_{4}=$ assets-liability ratio, $c_{5}=$ interests cash ratio, $c_{6}=$ net capital increasing ratio, $c_{7}=$ net operating cash growth rate. There are 4 grades of financial risk alarm condition including $N_{1}=$ No Alarm, $N_{2}=$ Light Alarm, $N_{3}=$ Moderate Alarm, $N_{4}=$ High Alarm[5].

Based on the statistical data of financial indicators, the classical field element model, sectional field element model and matter-element model of financial risk alarm condition are as follow.

Classical field element model: 


$$
\begin{aligned}
& R_{1}=\left[\begin{array}{ccc}
N_{1} & c_{1} & <0.01,35> \\
& c_{2} & <0,20> \\
& c_{3} & <0,3> \\
& c_{4} & <0,0.6> \\
& c_{5} & <0.15,1> \\
& c_{6} & <0,2> \\
& c_{7} & <0,20>
\end{array}\right. \\
& R_{2}=\left[\begin{array}{ccc}
N_{2} & c_{1} & <-0.01,0.01> \\
& c_{2} & <-0.1,0> \\
& c_{3} & <3,5> \\
c_{4} & <0.6,0.7> \\
c_{5} & <0,0.15> \\
c_{6} & <-0.3,0> \\
c_{7} & <-0.2,0>
\end{array}\right. \\
& R_{3}=\left[\begin{array}{ccc}
N_{3} & c_{1} & <-0.05,-0.01> \\
& c_{2} & <-0.5,-0.1> \\
& c_{3} & <5,8> \\
& c_{4} & <0.7,0.8> \\
& c_{5} & <-0.5,0> \\
& c_{6} & <-1,-0.3> \\
& c_{7} & <-1,-0.2>
\end{array} \quad R_{4}=\left[\begin{array}{ccc}
N_{4} & c_{1} & <-0.2,-0.05> \\
& c_{2} & <-1,-0.5> \\
& c_{3} & <8,10> \\
c_{4} & <0.8,2> \\
c_{5} & <-1,-0.5> \\
c_{6} & <-3,-1> \\
& c_{7} & <-12,-1>
\end{array}\right.\right.
\end{aligned}
$$

Sectional field element model:

$$
R_{p}=\left[\begin{array}{ccc}
N_{p} & c_{1} & <-0.2,35> \\
& c_{2} & <-1,20> \\
& c_{3} & <0,10> \\
& c_{4} & <0,2> \\
& c_{5} & <-1,1> \\
& c_{6} & <-3,2> \\
& c_{7} & <-12,20>
\end{array}\right.
$$

Limited by the paper length, we choose the listed company "HXKJ" as an example. Its matter-element model of financial risk alarm condition is as follow.

$$
R=\left[\begin{array}{ccc}
N & c_{1} & -0.114 \\
& c_{2} & 0.246 \\
& c_{3} & 1.367 \\
c_{4} & 0.559 \\
c_{5} & 0.275 \\
c_{6} & -0.107 \\
c_{7} & -4.384
\end{array}\right.
$$

Through the formula (3) and (7), correlative matrix is calculated as follow.

$$
K=\left[K_{j}\left(V_{k}\right)\right]_{7 \times 4}=\left[\begin{array}{cccc}
\text { No Alarm } & \text { Light Alarm } & \text { Moderate Alarm } & \text { High Alarm } \\
-0.591 & -0.548 & -0.427 & 2.927 \\
0.246 & -0.165 & -0.217 & -0.374 \\
1.367 & -0.544 & -0.727 & -0.829 \\
0.078 & -0.068 & -0.201 & -0.301 \\
0.208 & -0.147 & -0.275 & -0.517 \\
-0.048 & -0.054 & -0.084 & -0.298 \\
-0.365 & -0.355 & -0.308 & -0.800
\end{array}\right]
$$

Through correlative matrix and formula (5), $K^{*}\left(V_{1}\right)=K_{4}\left(V_{1}\right), \quad K^{*}\left(V_{2}\right)=K_{1}\left(V_{2}\right), \quad K^{*}\left(V_{3}\right)=K_{1}\left(V_{3}\right)$, $K^{*}\left(V_{4}\right)=K_{1}\left(V_{4}\right), \quad K^{*}\left(V_{5}\right)=K_{1}\left(V_{5}\right), \quad K^{*}\left(V_{6}\right)=K_{1}\left(V_{6}\right)$, $K^{*}\left(V_{7}\right)=K_{3}\left(V_{7}\right)$. The listed company's net asset earning rate $i=4$, so its alarm condition grade is "High Alarm"; its operating income growth rate, current ratio, assets-liability ratio, interests cash ratio and net capital increasing ratio $i=1$, so their alarm condition grade is "No Alarm"; its net operating cash growth rate $i=3$, so its alarm condition grade is "Moderate Alarm". Each indicator's weight is calculated through AHP method, so $W\left(\lambda, \lambda_{2}, \cdots ; \lambda_{7}\right)=(0.18,0.08, \cdots ; 0.29)$ Through formula $(6), \quad K_{1}(R)=-0.070 \quad, \quad K_{2}(R)=-0.282 \quad$ ，

$$
\begin{aligned}
& K_{3}(R)=-0.311 \quad, \quad K_{4}(R)=0.527 \quad, \quad \text { so } \\
& K_{i}(R)=\max _{1 \leq j \leq n} K_{j}(R)=K_{4}(R)=0.527 .
\end{aligned}
$$

So the listed company's financial risk alarm condition grade is "Highest Alarm". Among the seven indicators, the alarm condition of net asset earning rate is the highest one, so it is "High Alarm". Net asset earning rate is the critical

\begin{tabular}{|c|c|c|c|c|c|c|}
\hline \multirow{2}{*}{$\begin{array}{l}\text { Listed } \\
\text { company }\end{array}$} & \multicolumn{4}{|c|}{$\begin{array}{c}\text { Single indicator's alarm condition } \\
\text { grade }\end{array}$} & \multirow{2}{*}{$\begin{array}{c}\text { Comprehensive } \\
\text { alarm } \\
\text { condition } \\
\text { grade } \\
\end{array}$} & \multirow{2}{*}{$\begin{array}{c}\text { Critical } \\
\text { control } \\
\text { point }\end{array}$} \\
\hline & $c_{1}$ & $c_{2}$ & $\ldots$ & $c_{7}$ & & \\
\hline HXKJ & $\begin{array}{c}\text { High } \\
\text { Alarm }\end{array}$ & $\begin{array}{c}\text { No } \\
\text { Alarm }\end{array}$ & $\ldots$ & $\begin{array}{c}\text { Moderate } \\
\text { Alarm }\end{array}$ & High Alarm & $c_{1}$ \\
\hline GLLY & $\begin{array}{c}\text { No } \\
\text { Alarm }\end{array}$ & $\begin{array}{c}\text { No } \\
\text { Alarm }\end{array}$ & $\cdots$ & $\begin{array}{l}\text { Moderate } \\
\text { Alarm }\end{array}$ & No Alarm & $c_{7}$ \\
\hline$\ldots$ & $\cdots$ & $\cdots$ & $\cdots$ & $\cdots$ & $\cdots$ & $\cdots$ \\
\hline $\mathrm{S} * \mathrm{ST} \mathrm{ZG}$ & $\begin{array}{c}\text { Moderate } \\
\text { Alarm }\end{array}$ & $\begin{array}{l}\text { Light } \\
\text { Alarm }\end{array}$ & $\cdots$ & $\begin{array}{l}\text { Moderate } \\
\text { Alarm }\end{array}$ & High Alarm & $c_{4}, c_{5}$ \\
\hline GLLH & $\begin{array}{c}\text { No } \\
\text { Alarm }\end{array}$ & $\begin{array}{c}\text { No } \\
\text { Alarm }\end{array}$ & $\ldots$ & $\begin{array}{l}\text { High } \\
\text { Alarm }\end{array}$ & No Alarm & $c_{7}$ \\
\hline STDHA & $\begin{array}{c}\text { No } \\
\text { Alarm }\end{array}$ & $\begin{array}{c}\text { No } \\
\text { Alarm }\end{array}$ & $\cdots$ & $\begin{array}{c}\text { No } \\
\text { Alarm }\end{array}$ & No Alarm & $c_{6}$ \\
\hline JBFZ & $\begin{array}{l}\text { No } \\
\text { Alarm }\end{array}$ & $\begin{array}{c}\text { No } \\
\text { Alarm }\end{array}$ & $\ldots$ & $\begin{array}{l}\text { High } \\
\text { Alarm }\end{array}$ & High Alarm & $c_{5}, c_{7}$ \\
\hline DLSY & $\begin{array}{l}\text { Light } \\
\text { Alarm }\end{array}$ & $\begin{array}{c}\text { No } \\
\text { Alarm }\end{array}$ & $\cdots$ & $\begin{array}{l}\text { Light } \\
\text { Alarm }\end{array}$ & No Alarm & $c_{1}$ \\
\hline BSGF & $\begin{array}{c}\text { No } \\
\text { Alarm }\end{array}$ & $\begin{array}{c}\text { No } \\
\text { Alarm }\end{array}$ & $\cdots$ & $\begin{array}{l}\text { Light } \\
\text { Alarm }\end{array}$ & No Alarm & $c_{7}$ \\
\hline
\end{tabular}
control point of financial risk.

If other listed companies' data are calculated through the model, we can get the single indicator's alarm condition grade and comprehensive alarm condition grade. We also can find its critical control point of financial risk. The result is shown in Table I.

TABLE I. RESULTS OF FINANCIAL RISK ALARM CONDITION GRADING

In Table I, form the results of listed companies' single indicator's alarm condition and comprehensive alarm condition grade, the comprehensive alarm condition grade of HXKJ, S*STZG and JBFZ is "High Alarm". The other 14 listed companies are all "No Alarm". Among the 14 listed companies, single indicator's alarm condition of LJLY, ZQL and QSKG are all "No Alarm". Other 11 listed companies' certain single indicator exists alarm condition. STZG's comprehensive alarm condition grade is "High Alarm" except that current ratio is "No Alarm". The other 6 
indicators all exists certain alarm. Especially assets-liability ratio and interests cash ratio is "High Alarm". The critical control point of its financial risk is assets-liability ratio and interests cash ratio; STDHA's comprehensive alarm condition grade is "No Alarm". But its interests cash ratio is "Light Alarm" and net capital increasing ratio is "High Alarm". Its critical control point of financial risk is net capital increasing ratio.

\section{CONCLUSions}

The grading results from the grading model of financial risk alarm condition based on extension discrimination can explain the grading model's accuracy. In addition, the result is by classic field and sectional field. It is also influenced by the chosen indicators and their weights. It is a further researching issue how to decide the classic field and sectional field of financial risk alarm condition grade scientifically and how to choose the financial risk indicators reasonably and calculate the weights scientifically.

\section{ACKNOWLEDGMENT}

This research is supported by Major Scientific Research Project of Accounting Society in Hubei Province(NO. [2009]-2).

\section{REFERENCES}

[1] Zhang You tang, Zhang Yong, "Preliminary study on early-warning system of financial prosperity monitoring," Financial communication, 2006(8). 8-11 (in Chinese)

[2] Cai Wen, Yang Chun yan, "Extension engineering method," Science Press, 2000. 32-57(in Chinese)

[3] Feng Jing, Qi Wei, "Research on risk quantification in securities market based on extension theory," Technoeconomics \& Management Research, 2006(5). 43-45(in Chinese)

[4] Liu Na, Zhao Yong le, Shao Guang cheng, "Early-warning model of human resource management in enterprise," Science \& Technology Progress and Policy, 2007(10). 198-200(in Chinese)

[5] Li Yong, Jiang Ke shen, "Classification method of financial prosperity monitoring early-warning indicator and its application,' value engineering, 2009(8). 108-111 (in Chinese) 